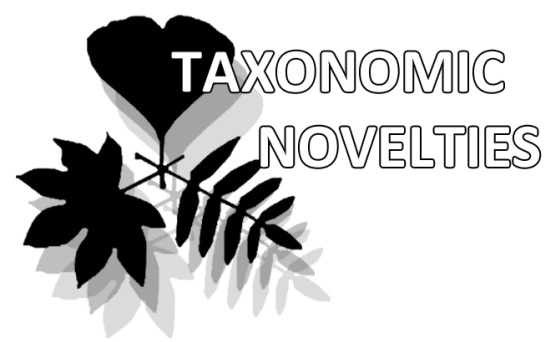

\title{
A New Species of Lonicera (Caprifoliaceae) from the Miocene of Primorye Region (the Russian Far East)
}

\author{
Boris I. Pavlyutkin
}

Boris I. Pavlyutkin

e-mail: pavlyutkin@fegi.ru

Far East Geological Institute FEB RAS, Vladivostok 690022 Russia

Manuscript received: 11.08 .2015 Review completed: 24.10 .2015

Accepted for publication: 26.10.2015

Published online: 26.10 .2015

\begin{abstract}
A B S T R A C T
A new species of the genus Lonicera, L. krassilovii Pavlyutkin, is described on the basis of leaf remains from the Miocene of Mount Zametnaya locality in Primorye. This species has features in pattern of tertiary veins. Brief information on recent and fossil species of Lonicera, and the composition of the flora accompanied by this new species are also given.
\end{abstract}

K e y w o r d s : Lonicera krassilovii, Miocene, plant fossil, leaf print

\section{P E 3 Ю M E}

Павлюткин Б.И. Новый виА Lonicera (Caprofoliaceae) из миоцена Приморского края (российский Аальний Восток). Приведены краткие сведения о современных и ископаемых видах Lonicera, приведен систематический список Аокальной миоценовой флоры Гора Заметная (Приморье), насчитывающей 41 виА из 30 родов и 20 семейств. Описан новый виА рода Lonicera (Lonicera krassilovii Pavlyutkin).

К $\boldsymbol{\Lambda}$ ю че в ы е с $\mathbf{\Lambda}$ о в а: Lonicera krassilovii, миоцен, ископаемое растений, отпечаток Аиста
Lonicera is one of the most diverse genera in the family Caprifoliaceae. It includes 180 to 200 species, according to different estimates. The Plant List (2010) enumerated at least 108 species as credible. Only in China 57 species can be found (Qiner et al. 2011). In the northeastern Asia 41 native species including subspecies were identified (Nedoluzhko 1986). This genus is distributed in both hemispheres, in areas under almost sub-Arctic and tropical climates, but mainly under warm-temperate and subtropical ones. The species of Lonicera are small trees, mostly shrubs, twining bines, mostly deciduous in abscission habit, rarely evergreen. The leaves are simple, oppositely-arranged, with entire margin, from densely pubescent with simple hairs to pubescent only along veins, often with cilia along margin. Venation is pinnate camptodrome. Petiole is short; the transition from the midrib to the petiole is gradual without thickening.

The megafossil remains of Lonicera in the Paleogene deposits in the Russian Far East were not found. The genus is not mentioned in the monographs with the description of the Paleogene floras (Tanai 1970, Kodrul 1999, Budantsev 1997, 2006, Ablaev 2000). The remains of this genus occasionally occur in the Miocene sediments. Thus, in the Miocene floras of Japan Lonicera protojaponica Tanai et Onoe (Tanai \& Onoe 1961, Huzioka \& Uemura 1974, Uemura 1988) and Lonicera sp. (Tanai \& Suzuki, 1965) were revealed. In the Russian Far East, the genus Lonicera takes part in a number of the Miocene floras (Akhmetiev 1973, Baranova et al. 1976, Sinelnikova et al. 1976, Chelebaeva 1978, Pavlyutkin 2005).

The Mount Zametnaya locality of the Miocene Ust-Suifun Formation (9155, Fig. 1), located $2 \mathrm{~km}$ to the southeast from known Nezhino locality of fossil flora (9180), was discovered in the early 2010s in Southern Primorye (Fig. 1). I have found numerous remains of the leaves and rare fruits. Plant megafossils are from the layer of yellow-white tuffites, lying within gravel and sand beds (Fig. 1). Plant remains are impression without cuticles and other organic matters, showing a little different color from the surrounding rock. They are preserved isolately without overlapping on the plant-beddings. Until now, I recognized 41 species in 30 genera belonging to 20 families (Table 1). The flora is dominated by leaves of Ulmus (3 species), Zelkova (1 species), Acer (4 species), Ampelopsis (2 species). Well-preserved leaves were found, corresponding to the features of the genus Lonicera. They have no analogues among the known fossil plants of Primorye. Their description is given below as a new species of the genus Lonicera.

CAPROFOLIACEAE A. L. DE JUSSIEU, 1789

Lonicera L., 1753

Lonicera krassilovii Pavlyutkin sp. nov.

Fig. 2a; Fig. 3: 1-11

Etymology. Named in honour of the famous Russian paleobotanist Valentin Krassilov.

Holotype. Far East Geological Institute, 9155/59, imprint of leaf, Primorye, Nezhino Town; Ust-Suifun Formation, Late Miocene (Fig. 2; Fig. 3: 1, 2 ).

Diagnosis. Lamina oblong-ovate, length/width ratio 1.4-3.0, base rotundate, apex gradually contracted, tip shortattenuate, margin entire, venation pinnate camptodromous, madrib moderate thick, slightly curved, thinning toward apex, secondary veins (5-7 pairs) unevenly spaced, diverging at angle 


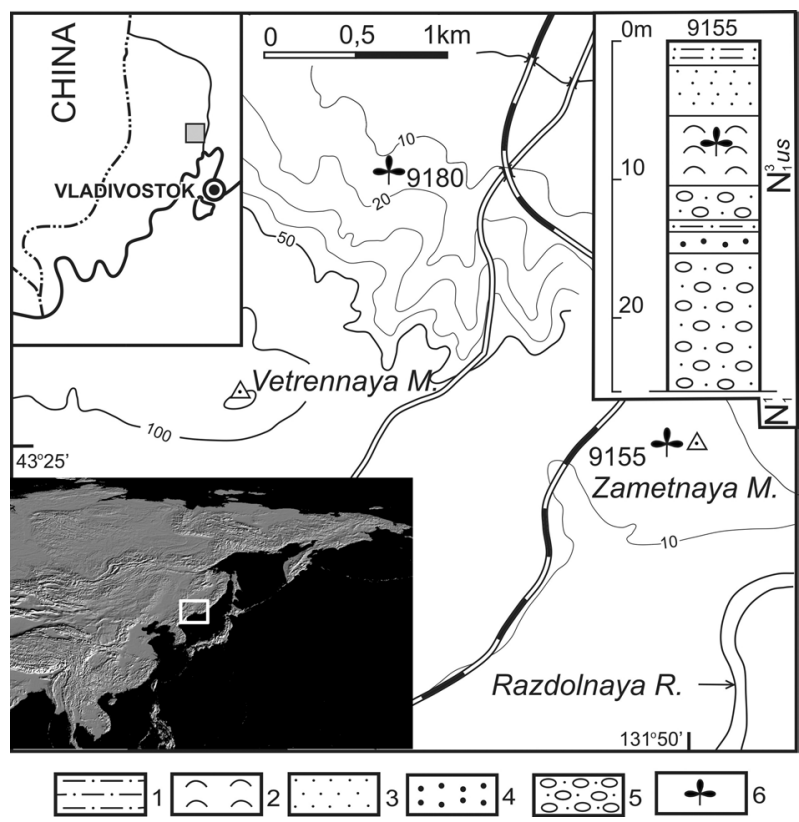

Figure 1 . Localities of the Miocene fossil flora $(9155,9180)$ and lithological column: 1 - siltstone, 2 - tuffite, 3 - sand, 4 - gravel, 5 - pebble, 6 - localities of plant remains

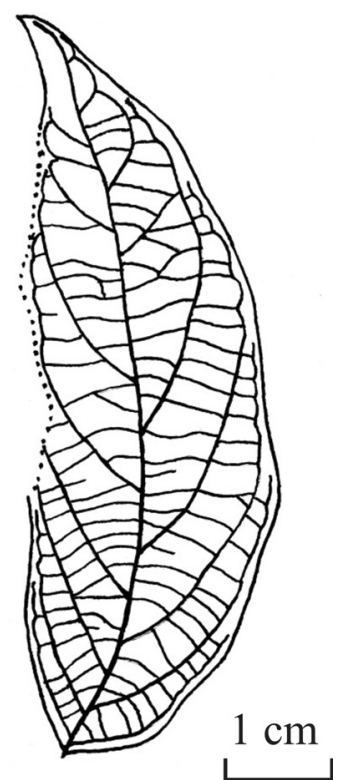

Figure 2 Lonicera krassilovii sp. nov. Specimen 9155/59 (holotype) (Fig. 3 6). The margin of lamina is entire, without teeth. Venation is pinnate, camptodromous. The midrib is moderately thick, from straight up curved, much thinner towards the tip. Alternate or opposite secondary veins (5-7 pairs) run from a primary vein irregular intervals at an angle of $45-55^{\circ}$. They gently bend upward, sliding along the edge, and connect to the overlying vein, forming a series of diminishing loops. There have been sporadic inserted veins reaching the main loop. Tertiary veins (up to 5 per $1 \mathrm{~cm}$ ) through rarely bifurcating, straight to slightly curved. The veins of next orders form a reticulum with tetra- and pentagonal areolations.
Comparison. L. krassilovii differs from majority known fossil species of honeysuckles in sharply expressed vein framework up to the venation of third order. It should be noted that a full-fledged comparison with known species in some cases difficult because of the poor quality and lack of necessary magnifications of photographic images. Leaves of Lonicera protojaponica (Tanai \& Onoe 1961) have a smaller lamina, different form of the apex, bifurcation of secondary veins and poorly visible tertiary veins. The difference from Lonicera sp. from the Rubeshibe Miocene flora (Tanai \& Suzuki 1965) manifested in the form of blade (obovate), the configuration of the secondary veins, reticular veins of tertiary veins. The leaves of Lonicera ochotensis Cheleb. (Baranova et al. 1976) differ in the blunt apex, slightly curved secondary veins and oblique orientation of tertiary veins to the secondary ones. The lamina of Lonicera sp. from the Miocene Mamontova Gora locality (Baranova et al. 1976) is characterized by more small size, different shape and nearly straight secondary veins. An incomplete leaf of honeysuckle (Lonicera sp.) from the Miocene Klassicheskaya Formation of Kamchatka (Chelebaeva 1978) differs in rounded apex and open (up to $60^{\circ}$ ) angle of running of secondary veins from a primary vein. Leaves of Lonicera

Table 1. Taxonomical composition of the Miocene flora (Zametnaya Mount Locality)

\begin{tabular}{|c|c|c|}
\hline Family & Species & $\begin{array}{l}\text { Speci- } \\
\text { mens }\end{array}$ \\
\hline Taxaceae & Taxus sulcata Baik. & 2 \\
\hline Cercidiphyllaceae & Cercidiphyllum crenatum (Ung.) R.W. Brown & 1 \\
\hline Lardizabalaceae & Sinofranchetia sp. (?) & 1 \\
\hline Ulmaceae & Ulmus drepanodonta Grub. & 26 \\
\hline- & U. suifunensis Goepp. & 33 \\
\hline- & U. nezhinoensis Pavlyutkin & 3 \\
\hline- & Zelkeva elongata Suz. & 18 \\
\hline- & Celtis subintegerrima Pavlyutkin & 7 \\
\hline- & C. inequilateralis Pavlyutkin & 4 \\
\hline Betulaceae & Betula sp. & 1 \\
\hline- & Alnus schmalhausenii Grub. & 5 \\
\hline- & Carpinus macrophylla Pavlyutkin & 9 \\
\hline- & Corylus takaminensis Uemura & 1 \\
\hline- & C. cordifolia Pavlyutkin & 1 \\
\hline Salicaceae & Salix baikovskajae Pavlyutkin & 1 \\
\hline- & Populus zaisanica Iljinskaja & 4 \\
\hline- & P. jarmolenkoi Iljinskaja & 1 \\
\hline- & Populus sp. & 1 \\
\hline Juglandaceae & Pterocarya primorica Pavlyutkin & 1 \\
\hline- & P. kryshtofovichii Cheleb. & 1 \\
\hline- & Carya miocathayensis $\mathrm{Hu}$ et Chaney & 1 \\
\hline Clethraceae & Clethra maximoviczii Nath. & 2 \\
\hline Rosaceae & Amelanchier sp. & 2 \\
\hline Leguminosae & Leguminosites sp. & 2 \\
\hline Rutaceae & Phellodendron grandifolium Iljinskaja & 5 \\
\hline- & Euodia sp. & 3 \\
\hline Aceraceae & Acer neabinoense Pavlyutkin & 14 \\
\hline- & A. monoides Shap. & 5 \\
\hline- & A. protomiyabei Endo & 1 \\
\hline- & Acer sp. & 12 \\
\hline Hippocastanaceae & Aesculus maius (Nath.) Tanai & 9 \\
\hline Oleaceae & Osmanthus sp. & 3 \\
\hline- & Syringa sp. & 6 \\
\hline Alangiaceae & Alangium kryshtofovichii Baik. & 5 \\
\hline- & Alangium sp. & 8 \\
\hline Cornaceae & Cornus miowaltherii $\mathrm{Hu}$ et Chaney & 8 \\
\hline Araliaceae & Acanthopanax ustsuifunensis Pavlyutkin & 1 \\
\hline Vitaceae & Parthenocissus sp. & 11 \\
\hline- & Ampelopsis sp. & 9 \\
\hline Caprifoliaceae & Lonicera sp. & 2 \\
\hline- & Lonicera krassilovii sp. nov. & 9 \\
\hline
\end{tabular}

Total: 19 families, 29 genera, 41 species. 

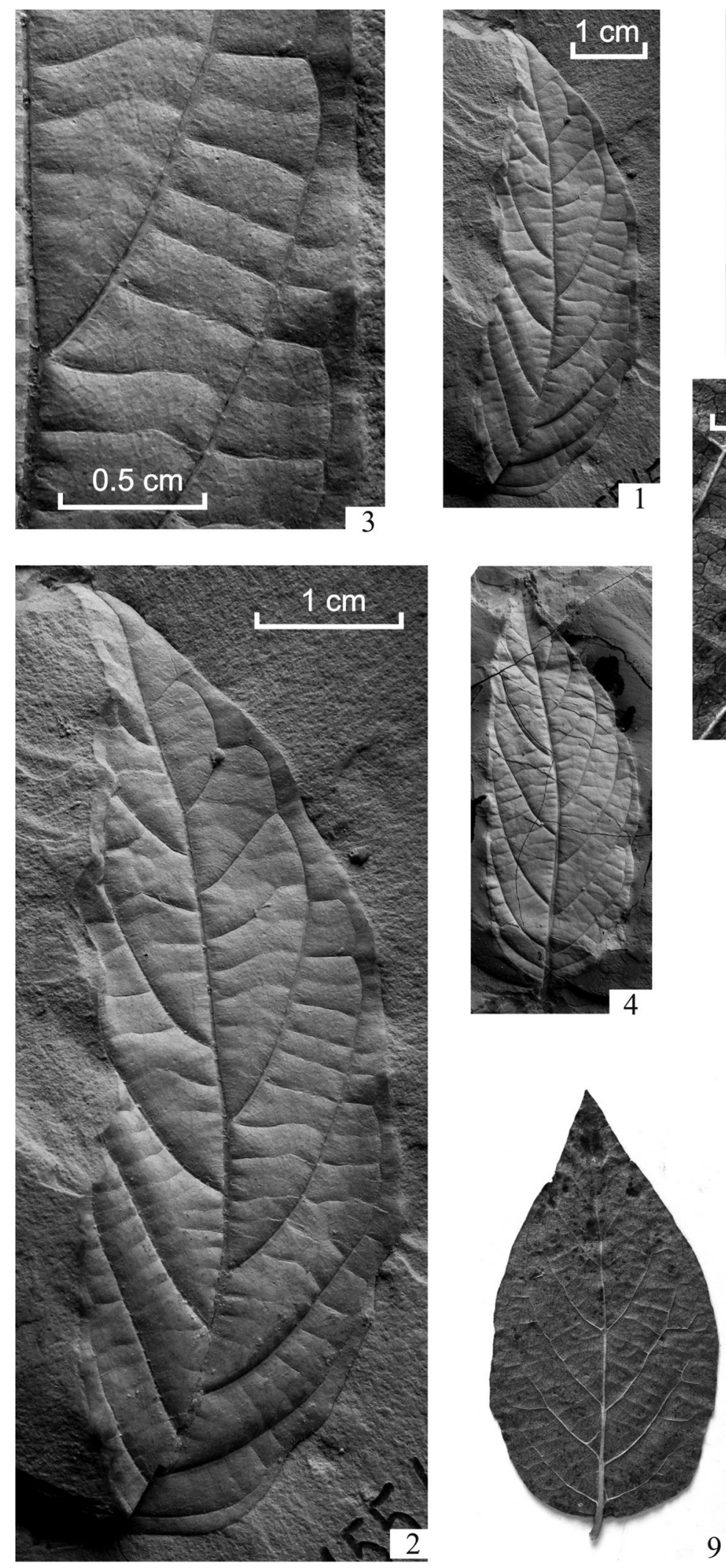
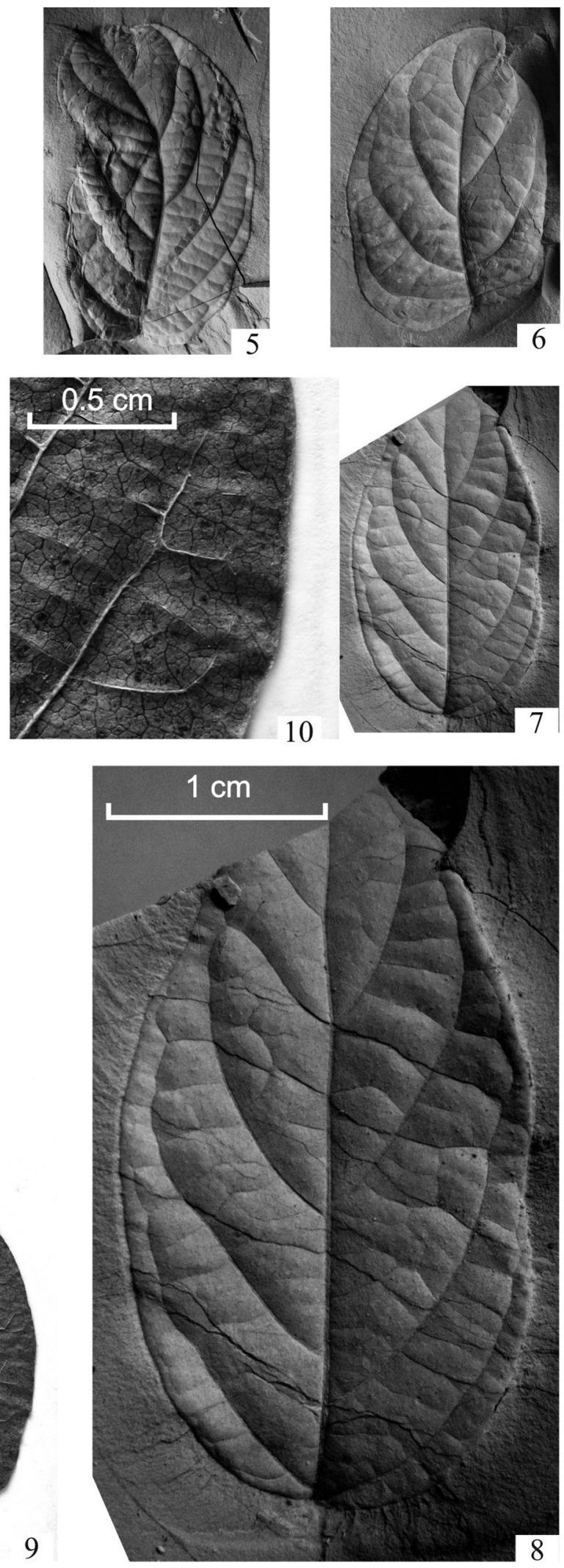

Figure 3 Lonicera krassilovii Pavlyutkin sp. nov.

1. Holotype, 9155/59; 2. From fig. 1, ×2; 3. Detail from fig. 1, ×4; 4-7. 9155/49; 9155/361; 9155/362; 9155/360; 8. From fig. 7, ×3; 9. Lonicera maximoviczii (Rupr.) Regel, Primorye Region, author's collection; 10. Detail from fig. 9, $\times 4$. The scale bar for Fig. 1 relates to Figs. 4-7, 9 
mulpensis Akhmetjev from the Miocene Botchinskaya Formation of Khabarovsk Region (Akhmetiev 1973) are characterized by not sharply pronounced tertiary veins, pattern which is poorly visible, branching of secondary veins near the margin. Leaves referred to Lonicera sp. 1 and Lonicera sp. 2. from the Miocene Novokachalinskaya Formation (Pavlyutkin 2005) have a different shape and almost straight branched secondary veins.

L. krassilovii has similarity with such recent species as L. maximoviczii (Rupr.) Regel (Fig. 3: 8, 9), widespread in the Primorye Region, Korea, and Northeast China.

Remarks. The collection, besides the described species, includes representatives of several genera having leaf blade with entire margin (Alangium, Cornus, Syringa, Phellodendron, Evodia). All of them are quite clearly differ from the leaves of this new species in venation, the presence of small rounded glandules along the margin of the leaf and a number of other features.

Material. 9 well-preserved leaves from the locality 9155 (Ust-Suifun Formation, Late Miocene).

\section{ACKNOWLEDGEMENTS}

The author would like to express his gratitude to reviewers of this paper - to Prof. K. Uemura and Prof. M.A. Akhmetiev for their helpful comments and advices.

\section{LITERAT URE CITE D}

Ablaev, A.G. 2000. Paleogene Biostratigraphy of the Coastal Region in South Primorye. Dalnauka, Vladivostok, 116 pp. (in Russian). [Аблаев А.Г. 2000. Биостратиграфия палеогена побережья юга Приморья. ВАадивосток: АаАьнаука. 116 с.].

Akhmetiev, M.A. 1973. Sikhote-Alin Miocene Flora (riv. Botchi). Nauka, Moskva, 124 pp. (in Russian). [Ахметьев M.A. 1973. Миоценовая фмора Сихотэ-Алиня (р. Ботчи). Москва: Наука. 124 с.

Baranova, Y.P., I.A. Iliinskaya, V.P. Nikitin, G.P. Pneva, A.F. Fradkina \& N.Y. Shvareva 1976. The Miocene of the Mamontova Gora (Stratigraphy and Paleoflora). Nauka, Moskva, 284 pp. (in Russian). [Баранова Ю.П., ИАьинская И.А., Никитин В.П., Пнева Г.П., Фрадкина А.Ф., Шварева Н.Я. 1976. Миоцен мамонтовой горы (стратиграфия и ископаемая флора). Москва: Наука. 284 с.].

Budantsev, L.Y. 1997. Late Eocene Flora of Western Kamchatkea. PetroRIF, Saint-Petersburg, 115 pp. (in Russian). [Буданцев А.Ю. 1997. Позднеэоценовая флора Западной Камчатки. Санкт-Петербург: ПетроРИФ. 108 с.].

Budantsev, L.Y. 2006. Early Paleogene Flora of Western Kamchatka. Nauka, Saint-Petersburg, 160 pp. (in Russian). [БyАанцев А.Ю. 2006. Раннепалеогеновая фмора ЗапаАной Камчатки. С-Пб: Наука. 160 с.].
Chelebaeva, A.I. 1978. Miocene floras of Eastern Kamchatka (Floras of stratotype of Korfovskaya Series). Nauka, Moskva, 156 pp. (in Russian). [Челебаева А.И. 1978. Миоценовые фморы Восточной Камчатки (фмора стратотипа корфовской серии). Москва: Наука. 156 с.].

Qiner, Y., S. Landrein, J. Osborne \& R. Borosova. 2011. Caprifoliaceae. In: Flora of China, vol. 19, pp. 616-641, Missouri Botanical Garden Press, St. Louis, and Science Press, Beijing.

Huzioka, K. \& K. Uemura 1974. The Late Miocene Sanzugawa flora of Akita Prefecture, Northeast Honshu, Japan. Bulletin of the National Science Museum, Tokyo, Japan 17(4): 326-366.

Kodrul, T.M. 1999. Paleogene phytostratigraphy of the South Sakbalin. Nauka, Moskva, 149 pp. (in Russian). [KoAрул Т.М. 1999. Фитостратиграфия палеогена Южного Сахалина. Москва: Наука. 149 с.].

Nedoluzhko, V.A. 1986. A systematic and geographic review of honeysuckles of Northeast Eurasia. Komarovskie Chtenia 33: 54-109 (in Russian). [Нелолужко B.A. 1986. Систематический и географический обзор жимолостей северо-востока Евразии // Комаровские чтения. Вып. 33. С. 54-109].

Pavlyutkin, B.I. 2005. The Mid-Miocene Khanka Flora of the Primorye. Vladivostok, Dalnauka, 216 pp. (in Russian). [Павлюткин Б.И. 2005. Среднемиоценовая ханкайская флора Приморья. ВАадивосток: Аальнаука. 216 с.].

Sinelnikova, V.N., L.I. Fotyanova, A.I. Chelebaeva, L.A. Skiba, E.G. Lupikina, A.L. Chepalyga \& Y.G. Drushits 1976. The Mio-Pliocene of the West Kamtschatka (The Erman Suite and Paleontological data Substantiation of its Age). Nauka, Moskva, 280 pp. (in Russian). [Синельникова В.Н., Фотьянова А.И., Челебаева А.И., Скиба А.А., Аупикина Е.Г., Чепалыга А.А., Арушиц Ю.Г. (1976) Мио-плиоцен Западной Камчатки (Эрмановская свита и палеонтологическое обоснование ее возраста). Москва: Наука. 280 с.].

Tanai, T. 1970. The Oligocene floras from the Kushiro Coal Field, Hokkaido, Japan. Journal of the Faculty of Science, Hokkaido University, Series IV 14(4):383-514.

Tanai, T. \& T. Onoe 1961. A Mio-Pliocene flora from the Ningyo-toge area on the border between Tottori and Okayama Prefectures, Japan. Reports, Geological Survey of Japan 187:1-62.

Tanai, T. \& N. Suzuki 1965. Late Tertiary floras from northeastern Hokkaido, Japan. Journal of the Paleontological Society of Japan 10:1-117.

The Plant List. 2010-2015 www.theplantlist.org/ browse/A/Caprifoliaceae/Lonicera. Missouri Botanical Garden. last accessed 20.10.2015

Uemura, K. 1988. Late Miocene Floras in northeast Honshu. National Science Museum, Tokyo, 174 pp. 